\title{
Influence of Winemaking Practices on the Characteristics of Winery Wastewater and Water Usage of Wineries
}

\author{
A. Conradie ${ }^{1 *}$, G.O. Sigge ${ }^{2}$, T.E. Cloete ${ }^{3}$ \\ (1) Institute for Wine Biotechnology, Stellenbosch University, Private Bag X1, Matieland 7602 \\ (2) Department of Food Science, Stellenbosch University, Private Bag X1, Matieland 7602 \\ (3) Department of Microbiology, Stellenbosch University, Private Bag X1, Matieland 7602
}

Submitted for publication: June 2013

Accepted for publication: October 2013

Key words: Winery wastewater, characteristics of winery wastewater, winemaking practices, cleaner production

\begin{abstract}
The winemaking industry produces large volumes of wastewater that pose an environmental threat if not treated correctly. The increasing numbers of wineries and the demand for wine around the world are adding to the growing problem. The vinification process includes all steps of the winemaking process, from the receipt of grapes to the final packaged product in the bottle. To fully understand all the aspects of winery wastewater it is important to know the winemaking processes before considering possible treatments. Winemaking is seen as an art and all wineries are individual, hence treatment solutions should be different. Furthermore, wastewater also differs from one winery to another regarding its volume and composition and therefore is it vital for a detailed characterisation of the wastewater to fully understand the problem before managing it. However, prevention is better than cure. There are a number of winemaking practices that can help lower the volume of the wastewater produced to decrease the work load of the treatment system and increase the efficiency of treatment.
\end{abstract}

\section{INTRODUCTION}

\section{Statistics of the wine industry}

Wine production plays a big role in the agricultural industry around the world. In 2012, a volume of 252. $9 \times 10^{6} \mathrm{hL}$ of wine was produced worldwide (OIV, 2013). The topproducing wine countries are Australia, Chile and the United States, followed by Argentina, France, Germany, Italy, Spain and South Africa (SA) (Devesa-Rey et al., 2011), with SA producing $10 \times 10^{6} \mathrm{hL}$ of wine (OIV, 2013).

Table 1 shows the number of wineries in SA per production category based on the volume of grapes crushed, which ranges from five tons to 75000 tons of grapes per

\section{TABLE 1}

Number of wineries in South Africa per production category in 2012 (SAWIS, 2013).

\begin{tabular}{cc}
\hline $\begin{array}{c}\text { Category } \\
\text { (tons of grapes crushed) }\end{array}$ & Number of wineries \\
\hline $1-100$ & 259 \\
$100-500$ & 159 \\
$500-1000$ & 52 \\
$1000-5000$ & 59 \\
$5000-10000$ & 16 \\
$>10000$ & 39 \\
\hline
\end{tabular}

harvest. The average winery crushes between one and 100 tons of grapes. White wine production makes up more than $70 \%$ of South African wine production (SAWIS, 2013).

\section{Composition of grape juice and wine}

The composition of grape juice and wine is compared in Table 2. There is almost no difference in the compounds found, other than their concentration, although additional compounds are formed during the winemaking process. Some of these compounds have to be removed before bottling. Fermentable sugars are transformed to alcohol according to the variety and the ripeness of the grapes; this is the most important difference between grape juice and wine (Stevenson, 2007).

\footnotetext{
Winemaking process

The fundamentals of winemaking have stayed the same since biblical times (Hands \& Hughes, 2001). What has changed is our ability to maintain the sterile environment required to produce top-quality wine (Halliday \& Johnson, 1994). It is important to understand the winemaking process when looking into the quantities of wastewater produced at wineries. Figure 1 presents a schematic diagram of the major steps in winemaking and where waste is produced. The
}

*Corresponding author: adelconradie@gmail.com

Aknowledgements: Stellenbosch University, for financial contribution from the Discretionary Fund of the Vice Rector (Research) 
TABLE 2

Composition of fresh grape juice and wine (Adapted from Stevenson, 2007).

\begin{tabular}{|c|c|c|}
\hline Component & $\begin{array}{c}\text { Grape juice } \\
\text { (percentage by volume) }\end{array}$ & $\begin{array}{c}\text { Wine } \\
\text { (percentage by volume) }\end{array}$ \\
\hline Water & 73.5 & 86 \\
\hline Carbohydrates & 25 & 0.2 \\
\hline Cellulose & 5 & - \\
\hline Sugar & 20 & - \\
\hline Alcohol (ethyl alcohol) & - & 12 \\
\hline Glycerol & - & 1 \\
\hline Organic acids & 93 & 35 \\
\hline Tartaric acid & 0.54 & 0.20 \\
\hline Malic acid & 0.25 & - \\
\hline Lactic acid & - & 0.15 \\
\hline Citric acid (plus traces of succinic and lactic acid) & 0.01 & - \\
\hline Succinic acid (plus traces of citric and malic acid) & - & 0.05 \\
\hline Minerals & 0.5 & 0.2 \\
\hline Calcium & 0.025 & 0.02 \\
\hline Chloride & 0.01 & 0.01 \\
\hline Magnesium & 0.025 & 0.02 \\
\hline Potassium & 0.25 & 0.075 \\
\hline Phosphate & 0.05 & 0.05 \\
\hline Silicic acid & 0.005 & 0.005 \\
\hline Sulphate & 0.035 & 0.02 \\
\hline Others & 0.1 & Traces \\
\hline Tannin and colour pigments & 0.13 & 0.1 \\
\hline Nitrogenous matter & 0.07 & 0.025 \\
\hline Amino acids & 0.05 & 0.01 \\
\hline Protein and other nitrogenous matter & 0.02 & 0.015 \\
\hline Volatile acids (mostly acetic acid) & - & 0.045 \\
\hline Esters & - & 0.025 \\
\hline Aldehydes & - & 0.004 \\
\hline Higher alcohols & - & 0.001 \\
\hline Vitamins & Traces & Traces \\
\hline
\end{tabular}

waste that is produced during the first step (destemming) is easily separated from the water, thus this is the only step that does not contribute directly to the chemical oxygen demand (COD) in the raw wastewater (Woodard \& Curran, 2006).

\section{WATER USE IN A WINERY}

Winemaking is seasonal and most of the activities related to it occur during the harvest period (Guglielmi et al., 2009). In the Southern Hemisphere, harvest is from the end of January to the beginning of April (Hands \& Hughes, 2001). Throughout the year, the water volume and pollution load vary in relation to the different processes taking place (Arienzo et al., 2009a). Large volumes of polluted water are produced by winemaking and may vary from one winery to another, depending on the production period and the unique style of winemaking of the different wineries (Agustina et al., 2007). A big difference can be found when comparing the water use of different wineries due to parameters such as the type of tanks, processing equipment and various winemaking techniques (Walsdorff et al., 2004).

Table 3 describes the different periods and winemaking practices during the year that contribute to the volume and quality of winery wastewater. Generally, the pre-vintage period (beginning to middle of January) is used to clean the cellar and equipment in preparation for the harvest. This is essential to prevent the growth of micro-organisms on the equipment, which can lead to contamination of the juice (Mercado et al., 2006). Due to the regular/daily cleaning of equipment during the harvesting period (end of January to beginning of April), there is a bigger demand for clean water (Rodriguez et al., 2007). After harvesting, hygiene is still an immense priority, despite the decrease in the volume of clean water used (due to activities in the cellar.) During the postharvest period, it is possible that there may be days without 
water usage in the wine cellar (P. Ngamane, Assistant winemaker, Hartenberg Wine Estate, Stellenbosch, personal communication, 2012).
In the winter months (rainy season) it is important that the storm water and winery wastewater are separated to prevent an increase in the amount of water that needs

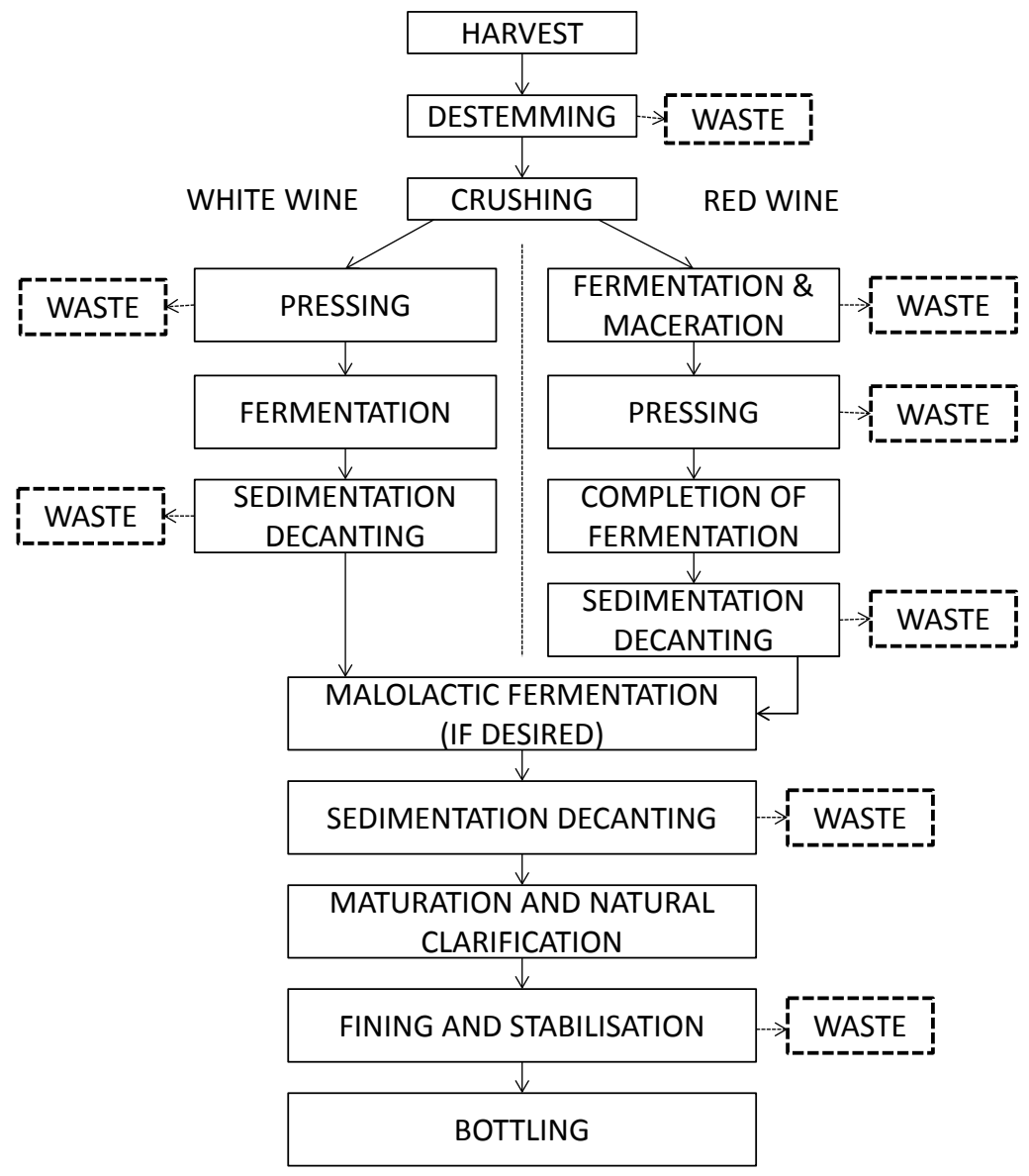

FIGURE 1

Diagram of organic waste generated in the process of making red and white wine (adapted from Arvanitoyannis et al., 2006;

Devesa-Rey et al., 2011).

TABLE 3

General winemaking practices during the different wine-production periods in wineries for South Africa (adapted from South Australian EPA, 2004).

\begin{tabular}{|c|c|c|}
\hline Period & Months & Action in cellar \\
\hline Pre-harvest & Beginning to middle of January & $\begin{array}{l}\text { Caustic washing of tanks and equipment, non-caustic washing } \\
\text { of equipment in preparation for vintage }\end{array}$ \\
\hline Early harvest & Middle to end of January & $\begin{array}{l}\text { Wastewater production is rapidly increasing and has reached } \\
40 \% \text { of the maximum weekly flow. Vintage operations } \\
\text { dominated by white wine production }\end{array}$ \\
\hline Peak harvest & February and March & $\begin{array}{l}\text { Wastewater generation is at its peak, vintage operations are at } \\
\text { a maximum }\end{array}$ \\
\hline Late harvest & Beginning of April & $\begin{array}{l}\text { Wastewater production has decreased; vintage operations are } \\
\text { dominated by red wine production }\end{array}$ \\
\hline Post-harvest & End of April and May & $\begin{array}{l}\text { Vintage operations have ceased. Caustic washing of the tanks } \\
\text { and equipment used during the harvest }\end{array}$ \\
\hline Non-harvest & June & $\begin{array}{l}\text { Filtering of white wines in preparation for bottling. Filtering } \\
\text { earth residues in waste water }\end{array}$ \\
\hline Non-harvest & July & Cleaning bottling equipment with caustic. Bottling white wines \\
\hline Non-harvest & August, September and October & $\begin{array}{l}\text { Put red wine to barrel and filtering of previous year's reds. } \\
\text { Water use is low }\end{array}$ \\
\hline Non-harvest & $\begin{array}{l}\text { November, December and beginning of } \\
\text { January }\end{array}$ & Cleaning bottling equipment with caustic. Bottling wines \\
\hline
\end{tabular}


TABLE 4

Estimates of volumes of virtual water used to produce wine.

\begin{tabular}{lll}
\hline $\begin{array}{l}\text { Volume of water per litre } \\
\text { of wine produced }\end{array}$ & $\begin{array}{l}\text { Estimated volume of total water used } \\
\text { for the wine industry worldwide }\end{array}$ & Reference \\
\hline $5-8$ & $1.3-2.1 \times 10^{9} \mathrm{hL}$ & Mosse et al. $(2011)$ \\
$1-4$ & $2.6-10.5 \times 10^{7} \mathrm{hL}$ & Bolzonella et al. $(2010)$ \\
$0.97-1.25$ & $2.5-3.3 \times 10^{7} \mathrm{hL}$ & Lucas et al. $(2010)$ \\
\hline
\end{tabular}

to be treated. It is also vital that the storm water remains unpolluted (Walsdorff et al., 2004).

The term 'virtual water' was first used by Allan in 1997 to describe water embedded in water-intense commodities (Allen, 1997; Wichelns, 2001). Since then the term has been widely used to describe the volume of fresh water used to produce a product, in this case wine, from the beginning of the process, through harvest, right to the end where it is in the bottle and ready for trade and consumption. Virtual water is being used to calculate the impact of the water footprint of specific production systems (Herath et al., 2012).

The virtual water used to produce one litre of wine varies according to different literature sources from around the world. Table 4 provides a summary of estimates of global winery water-use volumes according to the Organisation Internationale de la Vigne et du Vin (OIV, 2011) of wine produced in 2010. It is clear that there is a significant difference between the respective estimates.

Furthermore, the wine industry in South Africa has grown by $58 \%$ since 1997 , from $5.5 \times 10^{6} \mathrm{hL}$ in 1997 to 8.7 $\mathrm{x} 10^{6} \mathrm{hL}$ in 2012 (Fig. 2). This is a significant increase in wine, and goes hand in hand with the volume of water used and consequently the wastewater generated for every litre of wine produced (SAWIS, 2013).

\section{COMPOSITION OF WINERY WASTEWATER}

One of the biggest issues for the wine industry is the management of large volumes of wastewater (Bustamante et al., 2005). While wine production does not have a reputation as a polluting industry, the wastewater volumes worldwide are increasing and the wastewater has a high organic load, low $\mathrm{pH}$, variable salinity and nutrient levels, all of which indicate that the wastewater has the potential to pose an environmental threat (Mosse et al., 2011).

The four biggest components contributing to wastewater pollution in a winery are:

1. Sub-product residues: stems, skins, sludge, lees,tartar (Musee et al., 2005).

2. Lost brut production: must and wine occurred by spillage during winemaking activities (Mosse et al., 2011).

3. Products used for wine treatment: fining agents and filtration earths (Pérez-Serradilla \& Luque de Castro, 2008).

4. Cleaning and disinfection products (e.g. sodium hydrox-ide $(\mathrm{NaOH})$ and potassium hydroxide $(\mathrm{KOH})$ used to wash materials and equipment (Mahajan et al., 2010).

Table 5 shows the influence on wastewater of the different steps in the winemaking process.
An analysis of the average characteristics of wastewater showed that winery wastewater around the world and in different wineries in the same country has significant differences (Mosse et al., 2011). A summary of data for a few wineries is given in Table 6 to illustrate the differences in wastewater characteristics in different studies. The variance in wastewater composition complicates the issue of finding a general solution for wastewater treatment at different wineries (Andreottola et al., 2009). To find the correct treatment and reuse efficiencies for wastewater it is important to understand the detailed composition of the wastewater (Bustamante et al., 2005).

\section{Organic compounds in winery wastewater}

Most of the wastes generated in a cellar (80 to $85 \%$ ) are organic wastes (Ruggieri et al., 2009). The organic material in winery wastewater is generated from the grapes and wine (Valderrama et al., 2012). Figure 1 illustrates the points in the winemaking process where organic material contributes to the composition of winery wastewater. After destemming and pressing the grapes, (white and red) grape marc is produced that consists of grape skins and pips (Devesa-Rey et al., 2011). Despite the fact that the skins are kept separate from the wastewater system, the residue on the floors of the cellar and in the press will contribute to the high levels of COD (chemical oxygen demand) and variation in $\mathrm{pH}$ (Van Schoor, 2005). Apart from this, lees will form on the bottom of the wine tank or barrels after fermentation of the grape juice. This sediment will also have an effect on the organic compounds and COD of the wastewater (Mosse et al., 2011). COD is used to measure the oxygen demand of the organic load present in the wastewater (Andreottola et al., 2009). COD levels for grape marc can range from 15000 to 44900 $\mathrm{mg} / \mathrm{L}$, for lees from 27200 to $36100 \mathrm{mg} / \mathrm{L}$ and for wine from $26200 \mathrm{mg} / \mathrm{L}$ (Fillaudeau et al., 2008).

Bories et al. (1998, cited in Fillaudeau et al., 2008) studied the composition and components portions of winery wastewater. Their study showed that $90 \%$ of the organic component is ethanol, except during harvest, when it is mainly sugars (Fillaudeau et al., 2008). Ethanol concentrations of $4900 \mathrm{mg} / \mathrm{L}$ and sugar (glucose and fructose) of $870 \mathrm{mg} / \mathrm{L}$ were detected in winery wastewater with a dissolved COD of $12700 \mathrm{mg} / \mathrm{L}$ (Table 7). In addition to this, a study by Colin et al. (2005) showed that there is a linear correlation between COD and the ethanol concentration, and therefore the organic load of winery wastewater can be estimated when the ethanol concentration is known.

Contributing to the difference in the composition of the organic material in wastewater are the uncontrolled chemical reactions that take place in the wastewater (Mosse et al., 2011). Organic acids (acetic, tartaric, malic, lactic 


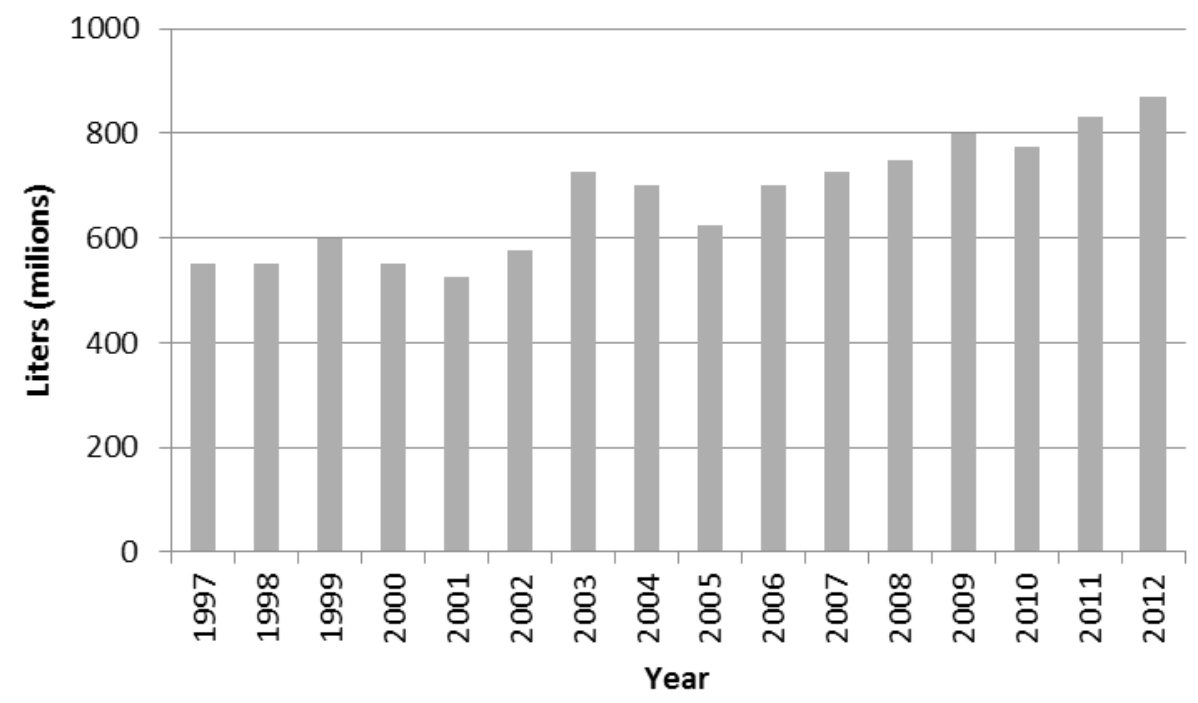

FIGURE 2

Wine production volumes in South Africa from 1997 to 2012 (SAWIS, 2013).

TABLE 5

Winery actions related to winery wastewater quantity and quality and the impact on the quality parameters (adapted from Van Schoor, 2005).

\begin{tabular}{|c|c|c|c|}
\hline Winery action & $\begin{array}{l}\text { Impact on } \\
\text { wastewater } \\
\text { quantity }\end{array}$ & $\begin{array}{l}\text { Impact on } \\
\text { wastewater } \\
\text { quality }\end{array}$ & $\begin{array}{l}\text { Impact on legal wastewater quality } \\
\text { parameters }\end{array}$ \\
\hline \multicolumn{4}{|l|}{ Cleaning water } \\
\hline Alkali washing and neutralisation & Up to $33 \%$ & $\begin{array}{l}\text { Increase in NA, } \mathrm{K} \text {, } \\
\text { COD and } \mathrm{pH}\end{array}$ & Increase in $\mathrm{EC}, \mathrm{SAR}, \mathrm{COD}$, variation in $\mathrm{pH}$ \\
\hline $\begin{array}{l}\text { Rinse water (tanks, floors, transfer lines, } \\
\text { bottles, barrels, etc.) }\end{array}$ & Up to $43 \%$ & $\begin{array}{l}\text { Increase in } \mathrm{NA}, \mathrm{P}, \mathrm{Cl} \text {, } \\
\text { COD }\end{array}$ & Increase in $\mathrm{EC}, \mathrm{SAR}, \mathrm{COD}$, variation in $\mathrm{pH}$ \\
\hline \multicolumn{4}{|l|}{ Process water } \\
\hline Filtration with filter aid & Up to $15 \%$ & Various contaminants & Increase in $\mathrm{COD}$ and $\mathrm{EC}$ \\
\hline Acidification and stabilisation of wine & Up to $3 \%$ & $\mathrm{H}_{2} \mathrm{SO}_{4}$ or $\mathrm{NaCl}$ & Increase in $\mathrm{COD}$ and $\mathrm{EC}$, decrease in $\mathrm{pH}$ \\
\hline Cooling tower waste & Up to $6 \%$ & Various salts & Increase COD and EC \\
\hline \multicolumn{4}{|l|}{ Other sources } \\
\hline Laboratory practices & Up to $5-10 \%$ & $\begin{array}{l}\text { Various salts, } \\
\text { variation in } \mathrm{pH} \text {, etc. }\end{array}$ & Increase $\mathrm{COD}$ and $\mathrm{EC}$ \\
\hline
\end{tabular}

EC - electrical conductivity; SAR - sodium absorption rate; COD - chemical oxygen demand

TABLE 6

Summary of reported winery wastewater characteristics.

\begin{tabular}{llllll}
\hline Parameters & Unit & Min & Max & Mean & References \\
\hline COD & $\mathrm{mg} / \mathrm{L}$ & 340 & 49105 & 14426 & $1-10$ \\
BOD & $\mathrm{mg} / \mathrm{L}$ & 181 & 22418 & 9574 & $4,6,7,10$ \\
$\mathrm{pH}$ & - & 3.5 & 7.9 & 4.9 & $2,4,6,8,9,10$ \\
Total solids & $\mathrm{mg} / \mathrm{L}$ & 190 & 18000 & 4151 & $2,4,5,8$ \\
EC & $\mathrm{S} / \mathrm{m}$ & 1.2 & 7.2 & 4.16 & $2,4,6,8$ \\
Suspended solids & $\mathrm{mg} / \mathrm{L}$ & 1000 & 5137 & 2845 & $4,9,10$ \\
\hline
\end{tabular}

The reference numbers in the last column refer to the following: 1. Agustina et al. (2007); 2. Arienzo et al. (2009b); 3. Bolzonella et al. (2010); 4. Bustamante et al. (2005); 5. Eusebi et al. (2009); 6. Mahajan et al. (2010); 7. Rodriguez et al. (2007); 8. Rytwo et al. (2011); 9. Yang et al. (2011); 10. Zhang et al. (2006) 
TABLE 7

Composition and breakdown of the COD of winery wastewater (Adapted from Fillaudeau et al., 2008)

\begin{tabular}{lcc}
\hline & $\begin{array}{c}\text { Concentration } \\
(\mathbf{m g} / \mathbf{L})\end{array}$ & COD (\%) \\
\hline COD raw & 14600 & \\
COD dissolved & 12700 & 100 \\
Ethanol & 4900 & 80.3 \\
Glucose and fructose & 870 & 7.3 \\
Glycerol & 320 & 3.1 \\
Tartaric acid & 1260 & 5.3 \\
Malic acid & 70 & 0.4 \\
Lactic acid & 160 & 1.2 \\
Acetic acid & 300 & 2.6 \\
\hline
\end{tabular}

and propionic), alcohols, esters and polyphenols play an important role in the composition of winery wastewater (Zhang et al., 2006; Mosse et al., 2012).

There is not a lot of research available on the organic components of winery wastewater, but it is essential to characterise the organic composition of winery wastewater to establish the impacts the wastewater will have on the environment (Bustamante et al., 2005; Mosse et al., 2011).

\section{Inorganic compounds in winery wastewater}

The composition of the inorganic compounds in winery wastewaters is dependent mainly (up to $76 \%$ ) on the components of the cleaning agents used in wineries (Table 5), except for potassium, which is present in high concentrations in grape juice (Mosse et al., 2011). Strong alkaline-based cleaning agents that are good for tartrate removal include caustic soda $(\mathrm{NaOH})$ and caustic potash $(\mathrm{KOH})$ (Sipowicz, 2007). Wineries that uses sodium-based cleaning agents have problems with the salinity of the wastewater if it is used for irrigation. The inorganic ions present are predominantly potassium and sodium, with low levels of calcium and magnesium, although the concentrations of both organic and inorganic constituents vary with differences in winemaking operations over time, as well as between individual wineries (Mosse et al., 2012).

\section{WHY MANAGE WASTE/WASTEWATER?}

In the past, the small volumes of winery wastewater that were produced by wineries had little effect on the immediate environment, but with increasing wine production all around the world, winery wastewater is a rising concern for the contamination of subsurface flow, soil and the environment (Grismer et al., 2003).

Research on the composition and volumes of winery wastewater is receiving more attention, and awareness of the effects of winery wastewater is assisting in the establishment and improvement of winery wastewater treatment systems (Devesa-Rey et al., 2011). Moderate quantities of winery waste and wastewater that are exposed to soils can increase the organic material due to the high concentration of soluble organic carbon in winery wastewater, which, in turn, will enhance the fertility of the soils (Bustamante et al., 2011).
Unfortunately, continuous exposure to the organic material can lead to organic overload that blocks the pores and lowers the quality of the soils immensely (Vries, 1972). The continuous addition of winery wastewater to soils can also contribute to high soil salinity, which can lead to dispersion (Halliwell et al., 2001).

The disposal of grape marc, a complex lignocellulose material made up of the skin, stalks and seeds, has also been a problem for wineries. In total, more than $20 \%$ of wine production is waste, comprising thousands of tons (Arvanitoyannis et al., 2006). Untreated grape marc can lead to several environmental threats, including foul odours and ground water pollution (Table 8). Decomposing grape marc provides the perfect environment for flies and pest to flourish (Laos et al., 2004). Leachate from the marc contains tannins and other chemical compounds that infiltrate the surface soil and ground water, leading to oxygen depletion (Arvanitoyannis et al., 2006). It is possible to use the marc in other industries (Kammerer et al., 2005); however, this can be expensive and therefore other, alternative solutions must be found (Ruggieri et al., 2009). The impact of winery wastewater on the biological and physiochemical properties of soil has not been researched in depth (Mosse et al., 2012). Table 8 shows the potential impacts of winery wastewater on the environment.

\section{MINIMISATION OF WATER USAGE AND POLLUTION LOAD}

Before discussing the different treatment options it is important to understand that the minimisation of winery wastewater should be the goal of all wineries (Lee \& Okos, 2011). The term 'zero discharge process' is used by Lee and Okos (2011) to refer to the substantial reduction of water and energy usage and ultimately to generate no waste during the production of food and beverages. Furthermore, water saving does not only cut the cost of fresh water used, but also reduces the cost accompanying the treatment of the wastewater (Fillaudeau et al., 2008). Avoiding waste is the most costeffective and often the easiest principle to implement better known as 'prevention (waste minimisation/cleaner production) is better than cure' (Chapman et al., 2001).

Not only is water a limited resource, but it can also contribute to the total cost of the final product. When the total cost of production water is calculated for the food and beverage industry it is vital not just to look at the cost of the volume used and the volume disposed, but also to look at the potential loss in income when the product is disposed as effluent (Casani et al., 2005). Fillaudeau formulated it as follows:

Water cost savings $=W_{\text {Saved }} \times\left(W_{\text {Rate }}+W_{\text {Treat }}\right)$ where $W_{\text {Saved }}$ is the volume of water saved, $W_{\text {Rate }}$ the incoming water rate (e.g. $\left.\$ / \mathrm{m}^{3}\right)$, and $W_{\text {Treat }}$ the treatment cost of the incoming water (Fillaudeau et al., 2008).

Wastewater treatment charge $=\mathrm{WW}_{\text {Saved }} \times \mathrm{WW}_{\text {Charge }}$ where $W W_{\text {Saved }}$ is the volume of wastewater saved and $W W_{\text {charge }}$ is the volumetric wastewater charge, which is generally a function of several parameters such as COD, total solid content as well as other specific components (Fillaudeau et al., 2008).

In Figure 3, the principles of cleaner production are 
TABLE 8

Potential environmental impacts of winery wastewater (adapted from South Australian EPA, 2004).

\begin{tabular}{|c|c|c|}
\hline $\begin{array}{l}\text { Winery } \\
\text { wastewater } \\
\text { components }\end{array}$ & Indicators & Effects \\
\hline Organic matter & BOD, TOC, COD & $\begin{array}{l}\text { Reduces oxygen levels - death of fish and other aquatic organisms. Odours } \\
\text { generated by anaerobic decomposition }\end{array}$ \\
\hline $\begin{array}{l}\text { Alkalinity/ } \\
\text { acidity }\end{array}$ & $\mathrm{pH}$ & $\begin{array}{l}\text { Death of aquatic organisms at extreme } \mathrm{pH} \text {. Affects the solubility of heavy metals } \\
\text { in the soil and availability and/or toxicity in water affects crop growth }\end{array}$ \\
\hline Nutrients & $\mathrm{N}, \mathrm{P}, \mathrm{K}$ & $\begin{array}{l}\text { Eutrophication or algal bloom. } \mathrm{N} \text { as nitrate and nitrite in drinking water supply can } \\
\text { be toxic to infants }\end{array}$ \\
\hline Salinity & $\mathrm{EC}, \mathrm{TDS}$ & $\begin{array}{l}\text { Imparts undesirable taste to water, toxic to aquatic organisms, affects water uptake } \\
\text { by crops }\end{array}$ \\
\hline Sodicity & SAR & $\begin{array}{l}\text { Affects soil structure, resulting in surface crusting. Low infiltration and hydraulic } \\
\text { conductivity }\end{array}$ \\
\hline Heavy metals & $\mathrm{Cu}, \mathrm{Ni}, \mathrm{Pb}, \mathrm{Zn}, \mathrm{Hg}$, etc. & Toxic to plants and animals \\
\hline Solids & TSS & $\begin{array}{l}\text { Can reduce light transmission in water, thus compromising ecosystem health, } \\
\text { smothers habitats, odour generated from anaerobic decomposition }\end{array}$ \\
\hline
\end{tabular}

BOD - biochemical oxygen demand; TOC - total organic carbon; TDS - total dissolved solids; TSS - total suspended solids

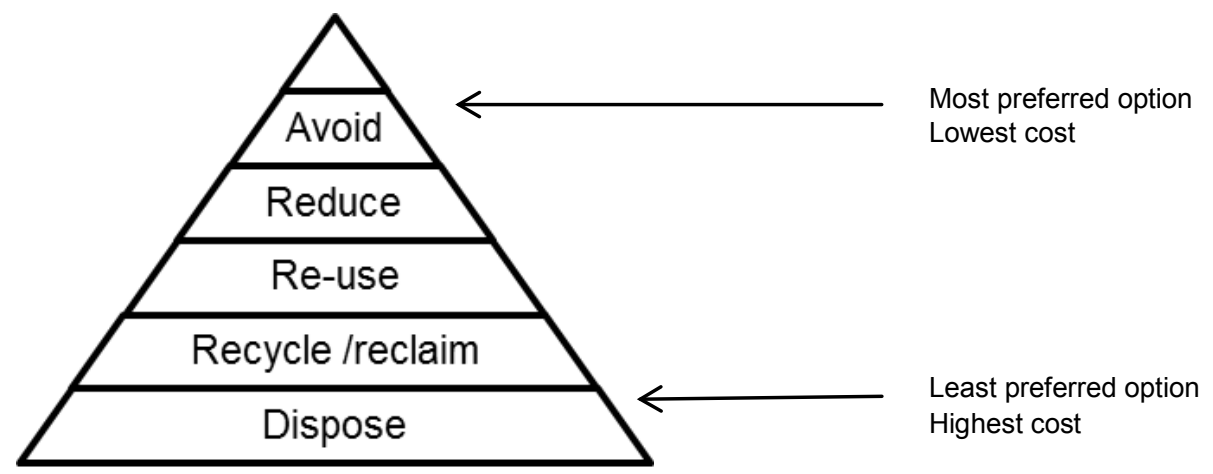

FIGURE 3

Hierarchy of cleaner production principles (Chapman et al., 2001).

illustrated, with the most preferred option, avoidance, as the most important principle (Chapman et al., 2001).

Water management is a particular concern in the wine industry and there are practices that can be implemented to help reduce the wastewater volumes of wineries by using cleaner production principles (Van Schoor, 2005). In general, a considerable volume of up to $30 \%$ can be reduced through simple changes with minimum capital input (Kirby et al., 2003). These changes include the evaluation of water usage in controlled areas; the improvement of planning and the control of water use; the option to reuse water; water recycling after treatment; and, lastly, the improvement of the layout of the processing area (Klemeš et al., 2009). In particular, the evaluation (water auditing) of water usage is important to all industries (Klemeš et al., 2008). Water auditing will not only help the winery to understand where the water is used, but also will indicate the place/process of largest usage. More importantly, it will point out the areas of unnecessary waste (Klemeš et al., 2008).

The first step for all wineries should be to install a water meter to control their water usage and identify water usage peaks, and to seek possible solutions (water-saving practices) to decrease water usage (Chapman, 1996). These water-saving practices include the use of nozzles on water pipes to avoid wastage. Water can be turned on and off conveniently each time the handle is compressed. The dry sweeping of floors with brushes and squeegees will also ensure the reduction of water usage before the floors are washed (Walsdorff et al., 2004). Furthermore, water-saving practices that could be introduced to winery staff with the appropriate training are listed in Table 9. In addition to these principles, it is vital that the management is $100 \%$ committed. Winewatch also recommends that all winery staff should be involved when a cleaner production strategy is developed, as this will heighten their awareness (Klemeš et al., 2008; Anonymous, 2009).

The next step in minimising the pollution load of the winery wastewater is the reduction of organic material in the raw wastewater. A number of practices that wineries can implement to achieve this is listed in Table 10. Firstly, 
TABLE 9

Water-saving practices (Chapman, 1996; Walsdorff et al., 2004).

\begin{tabular}{ll}
\hline Water-saving practices & Description \\
\hline Installation of water meter & Control water usage and identify water usage peaks \\
Use minimum water & Use no more water than needed for the job \\
High-pressure water system & Less water required for more efficient cleaning \\
Nozzle on water pipes & Avoid wastage of water so that a hose will not run when not required \\
Use of brushes and squeegee & Dry sweeping of floors before washing \\
Water awareness training & Developing of a cleaner production strategy \\
\hline
\end{tabular}

TABLE 10

Pollution load-minimisation practices (Chapman et al., 1996; Woodard \& Curran, 2006; Winewatch, 2009).

\begin{tabular}{|c|c|}
\hline Pollution load-minimisation practice & Description \\
\hline Installing mesh sieves & Prevent organic matter in winery wastewater \\
\hline Pomace animal feed/fertiliser & Mixed with stems and other solids \\
\hline Transfer lees and first rinse to separate tank & $\begin{array}{l}\text { Prevent the lees and diluted lees from draining into the wastewater } \\
\text { system }\end{array}$ \\
\hline $\begin{array}{l}\text { Ensure that conveyers, storage bins and tanks are } \\
\text { not overfilled }\end{array}$ & Reduce spillage \\
\hline Grape seed oil & Edible oils can be extracted form grape seeds \\
\hline Use fining agents that produce most compact lees & Reduce volume of lees \\
\hline Install in-line screening of organic matter & Reduce finer solids in wastewater \\
\hline Recovery of tartrates & Use in cooking as cream of tartar \\
\hline Resettle lees & Remove as much organic material as possible \\
\hline Keep transfers to a minimum & Reduce changes of spillage \\
\hline
\end{tabular}

the installation of mesh sieves in the floor, especially in the grape-processing section, will prevent organic material (stalks, skins and pips) from entering the wastewater system. Secondly, installing in-line screening in the initial stages of the treated wastewater system will reduce finer solids in the wastewater. To add to this, the accumulated lees after the initial alcoholic fermentation is thick and spillage can easily increase the COD (Fillaudeau et al., 2008) of the generated wastewater. The average COD of wine lees is $76000 \mathrm{mg} / \mathrm{L}$ (Boires et al.,1998, cited in Fillaudeau et al., 2008), therefore a small volume (of spillage when the tank is washed out after use) could have a vast influence on the raw wastewater of the winery. Thus it would be better if the lees and the first rinsing of the lees are transferred to a separate tank to prevent the lees and diluted lees from draining into the wastewater system (Woodard \& Curran, 2006). It goes without saying that lees that is more compactly settled will simplify this last-mentioned practice. The use of fining agents that produce more compactly settled lees should be considered by the winemaker to help reduce the volume of the lees (Anonymous, 2009). Chapman (1996) has drawn attention to the fact that avoidance is an important principle to consider when planning to reduce wastewater pollution, therefore, transfers of wine should be kept to a minimum to reduce the chances of spillage.

Primarily, the elimination of salt $(\mathrm{K}, \mathrm{Ca}, \mathrm{Na} \& \mathrm{Mg})$ usage in the winery should be promoted to reduce the EC and sodium absorption rate (SAR); consequently no treatment would be necessary before irrigation with the wastewater.
The use of non-sodium-based cleaning chemicals is advised by Chapman (Chapman, 1996). Replacing disinfectants and cleaning agents with ozone will result in lowering the EC and COD (Van Schoor, 2005). The initial cleaning with caustic can also be substituted with a high-pressure rinse or with heat/steam (Anonymous, 2009). When caustic is used for cleaning, the aim should be to re-use it (Chapman, 1996).

\section{CONCLUSIONS}

Wine production is a growing industry all around the world because the demand for wine is increasing and new wineries are being established. Subsequently, this industry produces large volumes of wastewater that potentially pose a risk to the environment and thus require treatment.

It is clear from the literature that the volumes of water used in wineries vary, but also that the wastewater characteristics differ significantly. This is an indication that the winemaking practices (white, red, rosé or blends; type of press; bottling operations; filtering and barrel work; to name a few) influence the wastewater characteristics. Contributing to this problem is that many winemakers see winemaking as an art and thus are not overly concerned with water use and wastewater treatment.

Even though the characteristics of wastewater produced by wineries differ immensely from winery to winery, there are practices that wineries can implement to reduce the volume and the pollution load. The implementation of cleaner production practices offers a partial solution for wineries to minimise wastewater produced and also reduce 
their water usage. It goes without saying that this, in return, will potentially reduce cost by avoiding wastages. Apart from these principles it is vital that the management of the winery is absolutely committed to contributing to the awareness and motivation of their employees.

A number of studies have recently shown that there is a correlation between winemaking practices and the characteristics of the wastewater, but further investigation is required to elucidate how specific winery practices influence the characteristics/composition of winery wastewater.

More specific information on these practices and their effects might encourage wineries to implement more efficient practices, thereby reducing water usage and the pollution loads of winery wastewater.

\section{LITERATURE CITED}

Agustina, T.E., Ang, H.M. \& Pareek, V.K., 2007. Treatment of winery wastewater using a photocatalytic/photolytic reactor. Chem. Engin. J. 135, 151-156.

Andreottola, G., Foladori, P. \& Ziglio, G., 2009. Biological treatment of winery wastewater: An overview. Water Sci. Technol. 60(5), 1117-1125.

Anonymous, 2009. Winewatch fact sheet 2. [Internet document]. Available http://environmentagriculture.curtin.edu.au/local/docs/winewatch/ Winewatch_Fact_Sheet_2.pdf (accessed 09/01/2012).

Arienzo, M., Christen, E.W. \& Quayle, W.C., 2009a. Phytotoxicity testing of winery wastewater for constructed wetland treatment. J. Hazardous Mat. 169, 94-99.

Arienzo, M., Christen, E.W., Quayle, W. \& Di Stefano, N., 2009 b. Development of a low-cost waste water system for small-scale wineries. Water Environ. Res. 81(3), 233-242.

Arvanitoyannis, I.S., Ladas, D. \& Mavromatis, A., 2006. Review: Wine waste treatment methodology. Int. J. Food Sci. Technol. 41, 1117-1151.

Bolzonella, D., Fatone, F., Pavan, P. \& Cecchi, F., 2010. Application of a membrane bioreactor for winery wastewater treatment. Water Sci. Technol. 62(12), 2745-2759.

Bustamante, M.A., Paredes, C., Moral, R., Moreno-Caselles, J., PerezEspinosa, A. \& Parez-Murcia, M.D., 2005. Uses of winery and distillery effluents in agriculture: Characterisation of nutrient and hazardous components. Water Sci. Technol. 51(1), 145-151.

Bustamante, M.A., Moral, R., Paredes, C., Peres-Espinosa, A., MorenoCaselles, J. \& Perez- Murcia, M.D., 2007. Agrochemical characterisation of the solid products and residues from the winery and distillery industry. Waste Management 28(2), 372-380.

Bustamante, M.A., Said-Pullicino, D., Agulló, E., Andreu, J., Paredes, C. \& Moral, R., 2011. Application of winery and distillery waste composts to a Jumilla (SE Spain) vineyard: Effects on the characteristics of a calcareous sandy-loam soil. Agric. Ecosys. Environ. 140, 80-87.

Casani, S., Rouhany, M. \& Knøchel, S., 2005. A discussion paper on challenges and limitations to water reuse and hygiene in the food industry. Water Res. 39, 1134-1146.

Chapman, J.A., 1996. Cleaner production for the wine industry. South. Australian Wine and Brandy Industry Association, Adelaide, Australia, pp $1-31$.

Chapman, J.A., Baker, P. \& Willis, S., 2001. Winery wastewater handbook: Production, impacts and management. Winetiles, Adelaide.
Colin, T., Boires, A., Sire, Y. \& Perrin, R., 2005. Treatment and valorisation of winery wastewater by a new biophysical process (ECCF). Water Sci. Technol. 51(1), 99-106.

Devesa-Rey, R., Vecino, X., Varela-Alenda, J.L., Barral, M.T., Cruz, J.M. \& Moldes, A.B., 2011. Valorization of winery waste vs cost of not recycling. Waste Management 31, 2327-2335.

Eusebi, A.L., Nardelli, P., Gatti, G., Battistoni, P. \& Cecchi, F., 2009. From conventional activated sledge to alternate oxic/anoxic process: the optimisation of winery wastewater treatment. Water Sci. Technol. 60(4), 1041-1048.

Fillaudeau, L., Bories, A. \& Decloux M., 2008. Brewing, winemaking and distilling: An overview of wastewater treatment and utilisation schemes. In: Handbook of water and energy management in food processing, Volume 1. Woodhead Publishing, pp 83-112.

Grismer, M.E., Carr, M.A. \& Shepherd, H.L., 2003. Evaluation of constructed wetland treatment performance for winery wastewater. Water Environ. Res. 75(5), 412-421.

Guglielmi, G., Andreottola, G., Foladori, P. \& Ziglio, G., 2009. Membrane bioreactors for winery wastewater treatment: Case studies at full scale. Water Sci. Technol. 60(5), 1201-1206.

Halliday, J. \& Johnson, H., 1994. Making white and red wine. In: The art and science of Wine. Mitchell Beazley, London, pp 88 - 142.

Halliwell, D., Barlow, K. \& Nash, D., 2001. A review of the effects of wastewater sodium on soil physical properties and their implications for irrigation systems. Soil Res. 39, 1259-1267.

Hands, P. \& Hughes, D., 2001 (2nd ed). How wine is made. In: New world of wine from the Cape of Good Hope. The definitive to the South African wine industry. Stephen Phillips, Somerset West, pp $84-91$.

Herath, I., Green, S., Singh, R., Horne, D., Van der Zijpp, S. \& Clothier, B., 2012. Water footprinting of agricultural products: A hydrological assessment for the water footprint of New Zealand's wines. J. Cleaner Production. doi: 10.1016/j.jclepro.2012.10.024

Kammerer, D., Kljusuric, J.G., Carle, R. \& Schieber, A., 2005. Recovery of anthocyanins from grape pomace extracts (Vitis vinifera L. cv. Cabernet Mitos) using a polymeric adsorber resin. Eur. Food Res. Technol. 220, 431437.

Kirby, R.M., Bartram, J. \& Carr, R., 2003. Water in food production and processing: Quantity and quality concerns. Food Control 14, 283-299.

Laos, F., Semenas, L. \& Labud, V., 2004. Factors related to the attraction of flies at a biosolids composting facility (Bariloche, Argentina). Sci Tot. Environ. 328, 33-40.

Klemeš, J., Smith, R. \& Kim, J. (2008). Assessing water and energy consumption and designing strategies for their reduction. In: Handbook of Water and Energy Management in Food Processing. Woodhead, pp 83-105.

Klemeš, J.J., Varbanov, P.S. \& Lam, H.L. (2009). Water footprint, water recycling and food industry supply chains. In: Handbook of Waste Management and Co-Product Recovery in Food Processing. Woodhead, pp 134-168.

Lee, W.H. \& Okos, M.R., 2011. Sustainable food processing systems - Path to a zero discharge: Reduction of water, waste and energy. Food Sci. 1, 1768-1777.

Lucas, M.S., Peres, J.A. \& Puma, G.L., 2010. Treatment of winery wastewater by ozone-bases advanced oxidation processes $(\mathrm{O} 3, \mathrm{O} 3 / \mathrm{UV}$ and $\mathrm{O} 3 / \mathrm{UV} / \mathrm{H} 2 \mathrm{O} 2$ ) in a pilot-scale bubble column reactor and process economics. Separation \& Purification Tech. 72, 235-241.

Mahajan, C.S., Narkhede, S.D., Khatik, V.A., Jadhav, R.N. \& Attarde, S.B., 2010. A review: Wastewater treatment at winery industry. Asian J. Environ. Sci. 4(2), 258-265. 
Mercado, L., Dalcero, A., Masuelli, R. \& Combina, M., 2006. Diversity of Saccharomyces strains on grapes and winery surfaces: Analysis of their contribution to fermentative flora of Malbec wine from Mendoza (Argentina) during two consecutive years. Diversity Food Microbiol. 24, 403-412.

Mosse, K.P.M., Patti, A.F., Christen, E.W. \& Cavagnaro, T.R., 2011. Review: Winery wastewater quality and treatment options in Australia. Aus. J. Grape Wine Res. 17(2), 111-121.

Mosse, K.P.M., Patti, A.F., Smernik, R.J., Christen, E.W. \& Cavagnaro, T.R., 2012. Physicochemical and microbiological effects of long- and shortterm winery wastewater application to soils. J. Hazardous Mat. 201-202, 219-228.

Musee, N., Lorenzen, L. \& Aldrich, C., 2005. Cellar waste minimization in the wine industry: A systems approach. J. Cleaner Production 15, 417-431.

OIV(Organisation Internationale de la Vigne et du Vin), 2013.Available http:// www.oiv.int/oiv/info/enpublicationsstatistiques (accessed 24/06/2013).

Pérez-Serradilla, J.A. \& Luque de Castro, M.D., 2008. Role of lees in wine production: A review. Food Chem. 111, 447-456.

Rodriguez, L., Villasenor, J., Buendia, I.M. \& Fernandez, F.J., 2007. Re-use of winery waste waters for biological nutrient removal. Water Sci. Technol. 56(2), 95-102.

Ruggieri, L., Cadena, E., Martínez-Blanco, J., Gasol, C.M., Rieradevall, J., Gabarrell, X., Gea, T., Sort, X. \& Sánchez, A., 2009. Recovery of organic wastes in the Spanish wine industry. Technical, economic and environmental analyses of the composting process. J. Cleaner Production 17, 830-838.

Rytwo, G., Rettig, A. \& Gonen, Y. (2011). Organo-sepiolite particles for the efficient pretreatment of organic wastewater: Application to winery effluents. Applied clay Sci. 51, 390-394.

SAWIS (South African Wine Industry and Systems), 2013. Available http://www.sawis.co.za/info/download/Book_2013_eng.pdf (accessed 24/06/2013).

Sipowicz, M., 2007. Winery cleaning and sanitation. Texas cooperative extension. Available http://winegrapes.tamu.edu/winemaking/ Sanitation\%20 Guide.pdf (accessed 21/12/2012).
South Australian Environment Protection Authority (EPA), 2004. Guidelines for Wineries and Distilleries. [Internet Document] Available http://www. epa.sa.gov.au/xstd_files/Industry/Guideline/guide_wineries.pdf (accessed 14/06/2012).

Stevenson, T., 2007. How wine is made. In: The new Sotheby's wine encyclopaedia: A comprehensive reference guide to the wines in the word. Dorling Kindersley Limited, London, pp 32 - 38.

Van Schoor, L.H., 2004. A prototype ISO 14001 Environmental Management System for wine cellars. $\mathrm{PhD}$ dissertation, Stellenbosch University, Private Bag X1, 7602 Matieland (Stellenbosch), South Africa.

Van Schoor, L.H. (2005). Winetech: Guidelines for the management ofwastewater and solid waste atexisting wineriesURL: http://www.ipw. co.za/content/guidelines/WastewaterApril05English.pdf. (12/04/2012)

Vries, J.D., 1972. Soil filtration of wastewater effluent and the mechanism of pore clogging. J. Water Poll. 44, 565-573.

Walsdorff, A., Van Kraayenburg, M. \& Barnardt, C.A., 2004. A multisite approach towards integrating environmental management in the wine production industry. Water SA. 30(5), 82-87.

Wichelns, D., 2001. The role of 'virtual water' in efforts to achieve food security and other national goals, with an example from Egypt. Agric. Water Managem. 49, 131-157.

Woodard \& Curran, 2006 (2nd ed). The winemaking industry. In: Industrial waste treatment handbook. Elsevier Inc, Oxford, pp 455 - 459.

Yang, R., Ma, Y., Zhang, W., Xu, R., Yin, F., Li, J., Chen, Y., Liu, S. \& $\mathrm{Xu}$ Y., 2011. The performance of new anaerobic filter process for high concentration winery wastewater treatment. 978-4244-6255-1/11. Power and Energy Engineering Conference (APPEEC), 2011 Asia-Pacific.

Zhang, Z.Y., Jin, B., Bai, Z.H. \& Wang, X.Y., 2006. Production of fungal biomass protein using microfungi from winery wastewater treatment Bioresource Technol. 99, 3871-3876. 